who work there are bound, in any case, by the Official Secrets Act, which in principle at least empowers the directors of the establishments to decide what should and should not be made public, and that there is nothing to prevent scientists at universities from carrying out similar work and publishing it. Although these two demands may seem quite out of court to many people in the Government, they are not lightly to be dismissed.

How, then, should the British Government respond to the present clamour? It would be hard and probably unwise for the Government to seek common ground with those of its crities who hold that hope of all defence against chemical and biological weapons is unrealistic, and that all research in this field should be abandoned. Apart from the work on the treatment of populations infected with biological weapons (which is where the case for a link between Porton and the Ministry of Health is strongest), a considerable effort now seems to be devoted to the development of methods of identifying biological and chemical agents and for providing early warning of attack. Science here could obviously be of great importance. It follows that the only reasonable case for asking that all research should be given up must be based on the assumption that these materials would never be used in anger. That is the kind of assumption which cannot lightly be expected of a prudent government.

There is a stronger case that research aimed at defence against chemical and biological weapons should continue, but that it should be carried out in a different environment or even that it should not be secret. The outstanding difficulty is that it is not practicable to look for an effective method of defence without also seeking to anticipate the kind of developments the weapons manufacturers have in mind. It would obviously be unwise for any government to make public information of this kind. That would be an act comparable with the random dissemination of nuclear weapons. It is fair to assure nations elsewhere that the benefits of this purely defensive research will be made generally available at some suitable opportunity, and that is a point on which the Government's critics should press. But to ask for the abandonment of secrecy is, unfortunately, unrealistic.

So is there no case to answer? The British Government stands in relationship to chemical and biological weapons much as does the Indian Government with nuclear weapons. It professes the lack of military intentions, it finds itself engaged in a programme of research which will at least provide a military option at some point in the future. As the Indian Government knows well enough, the problem is to make the good intentions credible. A transferring of establishments at Porton to the Ministry of Health would be a gesture, but hardly more than that. It would be much more to the point if the Government were to engage the kind of informed public discussion which, in the fifties, made it possible for ordinary people to understand the implication of nuclear weapons if not to live easily with them. There is, for example, no reason why the Porton establishments should not issue regular reports describing the general character of their secret work. Hitherto the Government has been far too coy.

There remains the awkward problem of the relationship with the United States. At present, it appears that there is a regular and fairly full exchange of information on chemical and biological weapons. In the context of Anglo-American arrangements on defence, this is not by itself remarkable, and there is no doubt that the purely defensive aims of the Porton establishment are greatly helped by the agreement. The other side of the coin is that development in the United States must benefit to some axtent from the work at Porton. It is entirely proper for the critics to ask whether this state of affairs is, in principle, compatible with the Government's intentions. The question cannot easily be answered. Consistency would, however, require that the Government should forsake the benefits of the special relationship with the United States. This is the point on which the crities are entitled to an answer.

\section{Aluminium in Trouble}

THE British Government's attempt to cut the import bill by establishing aluminium smelters in Britain is making slow and erratic progress. Barring the refusal of planning permission by Northumberland County Council (which is almost inconceivable), Alcan will be establishing a smelter in Lynemouth, near Blythe, using coal supplied under special contract by the National Coal Board. The terms under which the coal is to be supplied remain secret. All the Coal Board will say is that the contract provides for a supply of 0.5 million tons of coal in the early years, rising later to 1 million tons a year, and that the contract will last for 25 years. The decision not to site the smelter at Invergordon, but in Northumberland, nearer the coalfield which is to supply the coal, has meant that some re-negotiation has taken place. The cost of the coal (about $3 \cdot 25$ pence per therm, according to most estimates) is nevertheless much less than it costs to get it out of the ground, in the Northumberland coalfield at least. Although there will undoubtedly be improvements in productivity, this is a price which is likely to look more and more unrealistic as time passes. The Coal Board suggests that the Alcan agreement provides for at least some increase in costs, but, despite this, the suspicion remains that private users of coal, and big customers like the Central Electricity Generating Board, are being asked to subsidize the activities of Alcan.

Meanwhile, the negotiations between other companies and the electricity board about cheap electricity supplies for two more smelters have been making slow progress. Rio-Tinto Zinc, which is to build a smelter at Holyhead with British Insulated Callendar Cables, had originally intended to use part of the output of the Wylfa nuclear power station, but it is now conducting negotiations with the Gas Council and the Welsh Gas Board for the supply of natural gas for the smelter. Quite clearly there must be an air of unreality about these negotiations, because the Gas Council has not so far managed to come to terms with the oil companies who have found the gas in the North Sea. The Government will not sanction the building of the 
smelter until the power supply for it is settled, so there could be a long delay. British Aluminium, it is thought, will settle for the site at Invergordon, using electricity from the North of Scotland Hydro-electric Board. Negotiations for the contract, to last until the end of the century, are likely to be protracted, but the hydro board claims that this will not delay the commissioning of the smelter beyond 1971, the same year as Alcan.

In all this, one point has been almost entirely overlooked. Instead of an output of 240,000 tons from two smelters, the Government has now provided for an annual production of 320,000 tons, from three smelters. This side-stepped the problem of having to choose between the different companies, but has inevitably increased the concern felt by other producers of aluminium, principally those in Norway. Norway claims, not unreasonably, that the establishment of smelters in Britain involves subsidies which contravene the EFTA convention. It is bound to feel that the terms offered by the Coal Board include an element of subsidization. The Coal Board denies this, but the impression remains that Norway, and the users of coal in Britain, have been shabbily treated.

\section{What Next for ESRO?}

THE European Space Research Organization (ESRO) has at last had its first major success-the launching last month of the satellite ESRO 2 (rechristened IRIS now it is in orbit)-and has at the same time published its general report for 1967 which is a sad chronicle of all that befell it last year. Only because the report was obviously written some time before the cancellation of the TD 1 and TD 2 satellites and the crisis in ELDO, does it escape unmitigated gloom. Even so, it is clear that uncertainty about the future is ESRO's principal worry at the moment, and the organization is waiting anxiously for the meeting of the European Space Conference to be held in Bonn some time in the autumn, when it hopes that suspense will be lifted. The European Space Conference is a meeting of ministers concerned with space affairs from the various ESRO countries which last met almost a year ago, when it decided that ESRO should start no new projects for the time being at least.

That ban was imposed to give ESRO time to reorganize itself along the lines of the Bannier report, which recommended a greater delegation of authority and criticized ESRO for being too inflexible and complex for a scientific organization. This lesson has clearly been taken to heart. Last year saw the setting up of a new management structure. Replacing the clear separation between the scientific directorate and the technical directorate which was previously a feature of the organization's structure, the distinction is now between the part of the organization responsible for defining long-term policy and the part concerned with its implementation.

Clearly ESRO believes that the standstill imposed by the European Space Conference does not extend to thinking about new projects. Apart from detailed studies on the Large Astronomical Satellite project (LAS) and on communications satellites, it carried out a dozen feasibility studies for scientific satellites including further versions of the HEOS satellites, a solar satellite, a geostationary satellite, and a satellite with an adjustable orbit. It is also clear from the report that ESRO is concerned about its relationship with ELDO, the European Launcher Development Organization. For one thing, it is going to be more expensive to launch satellites with rockets developed by ELDO than by using the corresponding United States launchers. Another problem arguing against European launchers is that they will be larger than ESRO requires, at least in the foreseeable future. Although at first sight this seems to put ESRO in an enviable position as far as availability of launchers is concerned, the organization can hardly take advantage of this. Large launchers could only be fully utilized by combining some tens of small experiments in one satellite. Fitting together a large number of experiments in one satellite, making them compatible and incorporating all the necessary probes, solar cell panels and aerials is no mean task, as the Orbiting Geophysical Observatories developed in the United States have shown. The policy of the organization as far as launching rockets is concerned must again wait on the decisions of the European Space Conference.

It is no secret that the Italians are concerned about the way ESRO contracts are handled, and the general report admits that the policy of free tendering for contracts is not going to even out the differences in the technical capabilities of the member states. For example, up to the end of 1967 the value of contracts awarded to French industry was 38 per cent of all ESRO contracts, compared with the French contribution of 20 per cent to the ESRO budget. Italy, on the other hand, paying 11 per cent of ESRO's budget, received 7.5 per cent of the contracts. Britain receives 17 per cent of the contracts for its contribution of 24 per cent. Aware of this disparity, the organization feels it should encourage the member states to concentrate on particular aspects of space technology. Until this is achieved, ESRO seems to hope to stave off criticism by seeing that the percentage share of the contracts awarded to each member state is at least 70 per cent of its percentage contribution to the budget.

What is clear from the report is that the European Space Conference should not delay its decision on the future of European space co-operation much longer. European space contractors, and ESRO itself, need to know what kind of projects are likely to form the basis of the organization's work in the future. The meeting in Bonn in the autumn is likely to see an end to the more ambitious projects which ESRO has been tinkering with in the past, and a return to a more realistic view of what European technical co-operation is capable of at present. The sounding rocket programme, and the setting up of the range at Kiruna, invaluable for high altitude work, are examples of the kind of project ESRO can successfully undertake. An organization working at this level, together with a few launchings of small satellites, should provide a toe-hold for European space ambitions, and ensure that the facilities built up by ESRO are not wasted.

\section{Jodrell Bank in Wales}

Trre design studies for the Mark $\mathrm{V}$ radio telescope for Jodrell Bank are now well advanced and should be finished by the end of the year. With an assurance from the Science Research Council that the scheme will be given a measure of priority, the University of Man- 